\title{
The Role of the Notary Regional Supervisory Board in Preventing Legal Violations Committed by Notaries in Padang City
}

\author{
Dina Shabrina *; Azmi Fendri; Frenadin Adegustara \\ Faculty of Law, Universitas Andalas Padang, Indonesia \\ Email: d.shabrina@rocketmail.com
}

http://dx.doi.org/10.18415/ijmmu.v6i1.571

\begin{abstract}
The authority of the notary is very susceptible of legal violations. The role of the supervisory board is very important to maintain the notary profession in carrying out the authority. Law enforcement is urgently needed when a violation arises, in which a troubled notary must be sanctioned. Conducting research in the form of scientific work that studies the following research problems will be interesting: (1) what factors are the cause of legal violations committed by notaries in Padang City? (2) what is the role of the Regional Supervisory Board in preventing legal violations committed by notaries in Padang City? and (3) what actions are taken by the Regional Supervisory Board against the notaries who commit legal violations in Padang City. This study applies juridical empirical approach using secondary and primary data types. The Regional Supervisory Board of Padang City mentioned that the factors causing legal violations committed by the notaries in Padang City are that (1) the notary likes to accept a work that is not in accordance with the date stated in the deed and (2) the notary often does not see the client directly. Legal violations committed by notaries in Padang City can be prevented by conducting socialization and direct observation in the field. The action that can be taken if legal violations committed by notaries occurs is to carry out the inspection process in order to prove whether or not the notary has committed a violation.
\end{abstract}

Keywords: Role; Prevent; Legal Violation

\section{Introduction}

At present, the times are demanding that legal subjects get certainty from each of their legal actions. Current legal actions are closely related to business so that they become a driving force for the country's economy. The state has a responsibility in providing legal certainty in order to realize justice. In civil relations, the public wants certainty, order and legal protection. Written evidence has become a necessity of the society which is regulated in Article 1868 of the Civil Code, "an authentic deed is a deed whose form is determined by a law made by or before general officials who own authority for that matter at where the deed is made ". 
Authentic deeds have a permanent and perfect power so that they are absolute and are made by authorized officials. Notary is an authorized official to make authentic deeds. Authentic deeds made by notaries are evidence that clearly determines the rights and obligations of a person as a legal subject to ensure certainty, order and legal protection. A notary, as a public official, is one of the state bodies that has legal authority to provide legal services to the public; especially in the manufacture of authentic deeds as perfect evidence concerning legal actions in the field of civilization (Yudara, 2006).

Notary, as General Officer, is determined in Article 1 number (1) of Law Number 2 of 2014 concerning Amendment to Law Number 30 of 2004 concerning Notary Position, stating that "a notary public is an authorized official to make authentic deeds and have other authority as referred to in this Law or based on other Law". Furthermore, the authority of the general official is regulated in Article 15 concerning Notary Position.Based on the authority inherent in this notary's position, the State regulates supervision and sanctions for notaries who violate the rules for implementing positions. Notary must comply with the Law of Notary Position, notary code of ethics and also other regulations relating to notary position. The role of the notary, as a public official who serves the creation of authentic deeds for the society, is intended to protect the interests of the society so that supervision and guidance of the notary profession is very necessary. Supervision of notaries is carried out by the Minister. To carry out such supervision, a Supervisory Board is formed.

The basis for the formation of the Supervisory Board is regulated in Law Number 2 of 2014 concerning Notary Position. Such supervision includes behavior and implementation of notary position. In this case, it is affirmed in Article 67 paragraph (5) of the UUJN which states that "supervision as referred to in paragraph (1) covers the behavior of notaries and the implementation of notary positions". The Supervisory Board is a body that has the authority and obligation to carry out guidance and supervision against the notary. Supervision of the notary is intended so that the notary performs his/her office duties based on and follows the laws and regulations governing the position of the notary. In carrying out his/her office duties, a notary must hold and based on the laws and regulations governing the position of a notary. It means that everything mentioned in the regulation that governs the position of a notary must be followed.

Based on Article 68 of the Act on Notary Position, it is stated that the Supervisory Board consists of the Regional Supervisory Board (MPD), the Area Supervisory Board (MPW), and the Central Supervisory Board (MPP). The Regional Supervisory Board is the most important benchmark in monitoring notaries because the scope of work of the Regional Supervisory Board is closer to the area of the notaries; therefore, supervision and guidance can be conducted more easily. The authority of the Regional Supervisory Board is regulated in the Law of Notary Position (UUJN), Regulation of the Minister of Law and Human Rights of the Republic of Indonesia Number M.02.PR.08.10 of 2004, and Decree of the Minister of Law and Human Rights Republic of Indonesia Number M.39- PW.07.10. 2004. Article 70 of the Notary Position Act (UUJN) also regulates the authority of the Regional Supervisory Board (MPD).

The authority of the notary is very susceptible of legal violations. The role of the supervisory board is very important to maintain the notary profession in carrying out the authority. Law enforcement is urgently needed when a violation arises, in which a troubled notary must be sanctioned. Based on UUJN, when a notary, in carrying out his/her position, is proven to have committed a violation, he/she must be responsible and subject to sanctions in the form of civil sanctions, administrative sanctions, criminal sanctions, notary position sanctions and/or a combination of sanctions. The articles containing sanctions are Article 7 paragraph (2); Article 16 paragraph (11), paragraph (12), paragraph (13); Article 17 paragraph (2), Article 19 paragraph (4); Article 32 paragraph (4); Article 37 paragraph (2); Article 54 paragraph (2), and Article 65A. Violations to these articles will be subject to sanctions starting from written warnings to disrespectful termination of office. Meanwhile, if a notary makes a mistake that 
causes the power of proof of the deed changes into a deed under the hand, the related parties may request compensation from the notary. This may happen if the notary violates Article 41 in which he/she does not implement Articles 38, 39 and 40; Article 44 paragraph (5); Article 48 paragraph (3), Article 49 paragraph (4), Article 50 paragraph (5) and 51, and paragraph (4) appropriately.

In the working area of the Notary Regional Supervisory Board in Padang City, based on data from the Padang Regional Supervisory Board, there were reports of legal violations committed by notaries throughout 2017; in this case, the violation is that the notary does not provide legal counseling to related parties so that it causes harm. In addition, the notary is partial to one party that causes harm to the other party. Moreover, there are also multiple dual positions besides the position of the notary. A law violation committed by a notary may change the deed he/she has made into a certificate under the hand or the deed may be requested for cancellation. The Regional Supervisory Board must prevent the notary from committing an illegal act, because the notary profession is a public official appointed by the state to create legal certainty in the area of civil law. Notaries must uphold dignity and carry out their duties according to Law Number 2 of 2014 concerning Notary Position and applicable Law relating to the notary profession.

\section{Literature Review 2.1 Authority Theory}

The implementation of the functions of government, power and authority is very important. In the Big Indonesian Language Dictionary (KBBI), the word "authority" means the right and power to act, authority, power to make decisions, govern and delegate responsibility to others. 'The term 'authority' is used as a noun. This term is often confused with the term rights. The term authority or right is often equated with the term "bevoegheid" in Dutch legal terms. In the literature of Dutch administrative law, the question of authority is an important part and the initial part of administrative law because the object of administrative law is the authority of the government (bestuurbevoegdheid). According to Phillipus M. Hadjon, in further examination, there is a slight difference between the term authority and the term bevoegheid. The difference lies in its legal character. The term bevoegheid is used in the concepts of public law and the concept of private law. In addition, in our law, the term authority should be used in the concept of public law. ${ }^{2}$ Authority is generally interpreted as the power to carry out all public legal actions. Theoretically, the authority derived from the legislation is obtained through three ways, i.e. attribution, delegation and mandate.

In this paper, the concept of authority is only limited to the authority of the government (bestuurbevoegdheid). The scope of government authority not only includes the authority to make government decisions (besluit), but also all authority in order to carry out their duties (Fauzi, 2008). Authority has an important role in running the government, in which it contains rights and obligations in a public legal relationship.

\subsection{Responsibility Theory}

The legal responsibility theory is a theory that analyzes the responsibilities of legal subjects or actors who have committed acts against the law or criminal acts to bear costs or losses or carry out crimes for their mistakes or because of their negligence (Salim and Nurbani, 2014). To bear is defined as being

\footnotetext{
${ }^{1}$ Kamus Besar Bahasa Indonesia (Indonesia Dictionary), Balai Pustaka, Jakarta, page 1011

${ }^{2}$ Phillipus M. Hadjon, Paper on Authority, Airlangga University, Surabaya, 1986, page 20
} 
willing to bear the costs (managing, maintaining), guaranteeing, stating the state of willingness to carry out obligations. ${ }^{3}$

According to Kelsen (2007), in his theory of legal responsibility, states that "a person is legally responsible for a certain act or that he or she bears legal responsibility; the subject of the law means that he/ she is responsible for a sanction in the event of a contravention. Failure to exercise caution which is required by law is called negligence. In addition, oversight is usually seen as one other type of error (culpa), although it is not as severe as the mistakes that are fulfilled because of anticipating and wanting, with or without evil intentions or harmful consequences (Kelsen, 2007).

The principle of legal responsibility can be divided into 2 (two) types, i.e. liability based on fault and strict liability (Hardjasoemantri, 1994)

\subsection{Legal Certainty Theory}

Notary, in carrying out his/her job duties, must be guided normatively to the legal rules relating to all actions that will be taken and then set forth in a deed (Adjie, Habib, 2009). Acting on the applicable legal rules will confirm to the related parties that the deed made by or before a notary is in accordance with the applicable legal rules. Thus, if a problem occurs, the notary deed can be used as a guideline for evidence by all parties. ${ }^{4}$

Legal certainty theory contains two meanings, as follows:

1) General rules that make individuals know what is permissible and what is not.

2) Legal certainty for individuals from government arbitrariness.

By the existence of general legal rules, individuals can find out what the state can charge or do with individuals. Legal certainty is not only in the form of articles and laws but also consistency in judges' decisions between one judge's decision and the others for a similar case that has been decided (Marzuki, 2009).

Basically, law is essentially an abstract matter, even though its manifestations are concrete. People's perception of the law is diverse; depending on which angle they look at (Braithwaite, 2002). Judges will view the law from their point of view as judges, legal scientists will view the law from the point of their scientific profession, common people will view the law from their perspective and so on. Legal certainty is a question that can only be answered normatively, not sociologically. Normative legal certainty is when a regulation is defined and promulgated because it regulates clearly and logically (Raitio, 2003). Obviously, in this case, it does not cause doubt (multi-interpretation) and logically is that it becomes a norm system with other norms so that it does not clash or does not cause norm conflicts (Habermas, 2015).

\section{Research Method}

\subsection{Research Approach}

The approach that will be used in this study is an empirical juridical approach which in addition to seeing positive legal aspects, this study also looks at what is applied in the field and society (Buchanan et al., 2014). The data examined initially are secondary data which are then followed by research on

\footnotetext{
${ }^{3}$ Departemen Pendidikan dan Kebudayaan (Department of Education and Culture), 1989, Kamus Besar Bahasa Indonesia (Indonesia Dictionary), Jakarta: Balai Pustaka), page 899

${ }^{4}$ Habib Adjie, Indonesian Notary Law: Thematic Interpretation of Law No. 30 of 2004 concerning Notary Position, Bandung: PT Refika Aditama, 2008, page 37
} 
primary data in the field, i.e. research on the role of the Notary Regional Supervisory Board in preventing legal violations committed by notaries in Padang City.

\subsection{Characteristic of the Research Method}

This research is a descriptive analytical study that describes and explains the research object in a complete, clear and objective manner that has to do with research problems (McConville, 2017). In this study, the authors describe how the role of the Notary Regional Supervisory Board in preventing legal violations committed by notaries in Padang City.

\subsection{Data Types and Sources}

This study uses the following data:

a. Primary data: data obtained directly in the field through interviews with respondents (notaries).

b. Secondary data that consists of legal materials such as:

1) Primary legal materials, i.e. binding legal materials such as legislation and jurisprudence, including:

a) 1945 Constitution of the Republic of Indonesia;

b) Law Number 30 of 2004 concerning Notary Position;

c) Law Number 2 of 2014 concerning Amendment to Law Number 30 of 2004 concerning Notary Position;

d) Code of Civil Law;

2) Secondary legal material, namely legal material that provides an explanation of primary legal materials, among others:

a) Literature or the results of writing in the form of research findings including books, and scientific journals;

b) The work of legal practitioners and the writings of experts;

c) Legal theories and scholarly opinions through the literature they use.

3) Tertiary legal material, i.e. legal material that provides guidance and explanation of primary and secondary legal materials, such as legal dictionaries, and binding legal materials, especially in the area of notary.

\subsection{Data Collection Techniques}

Data collection required in this legal research is carried out using the following techniques:

a. Literature studies): research conducted by visiting the library in order to collect data relating to the research problem, which is carried out by studying documents. Document study includes the study of legal materials consisting of primary legal materials, secondary legal materials, and tertiary legal materials. Document study is a technique of collecting data by looking for the theoretical foundation of the problem under study by studying documents and data relating to the object to be studied.

b. Interview: the role of face-to-face person that is when the interviewer asks questions designed to obtain answers that are relevant to the research problem to the respondent. This interview is conducted by semi-structured technique, i.e. by making a list of questions in which during the 
implementation, the addition or development of questions with a focus on the problem under study is allowed.

\subsection{Data Processing and Analysis Techniques}

In this study the processing of the data obtained after the study was carried out by editing and coding. Editing is the process of reviewing the records, files, information collected by data seekers that are expected to improve the quality of reliability of the data to be analyzed. In the coding process, after editing, it is given certain signs or codes to determine the relevant or required data.

This study applies qualitative data analysis; i.e. a description of the data that are analyzed based on legislation and experts' opinions. It is then explained in descriptive sentence that has been analyzed, interpreted, and drawn conclusions in accordance with the problems discussed.

\section{Findings and Discussion 4.1 Factors Causing Violations of Law}

A lot of violations committed by the notary principally are not due to the notary's ignorance of the prohibition. However, the violation occurred because of the low moral awareness and ethics of the notary in carrying out his/her position. Based on the data the authors obtained from the results of interviews or written data from members of the Regional Supervisory Board in Padang City throughout 2017, there were reports of legal violations committed by the notary. In this case, the violation committed is that the notary does not provide legal counseling to the related parties so that it causes loss and partiality to one of the parties which causes harm to the other party. In addition, there were also violations of multiple dual positions in addition to the notary him/herself.

Apart from all forms of legal violations committed by notaries, the authors are interested in conducting research on the role of the Notary Regional Supervisory Board in preventing legal committed violations by notaries in Padang City. Based on the results of the interview with one of the members of the Supervisory Board of Padang City, Mrs. Desmawita, she mentioned that one of the factors that caused the violation of law committed by the notary in Padang City was that the notary likes to accept a work that was not in accordance with the date stated in the deed and often does not see the client directly. Furthermore, she stated that this is one of the triggers for the notary in violating the law. ${ }^{5}$

Table of Violations Committed by Notaries in 2017-2018

\begin{tabular}{|c|c|}
\hline Number & Violations Committed by Notaries \\
\hline 1. & The notary does not provide legal counseling to related parties so that it causes losses \\
\hline 2. & $\begin{array}{l}\text { The notary likes to accept a work that was not in accordance with the date stated in the } \\
\text { deed }\end{array}$ \\
\hline 3. & $\begin{array}{l}\text { The notary has never sent a monthly report to the office of area or Regional } \\
\text { Supervisory Board (MPD) }\end{array}$ \\
\hline 4. & $\begin{array}{l}\text { There are several supporting protocol books that have not been signed, numbered and } \\
\text { stamped by MPD }\end{array}$ \\
\hline 5. & Notary workspace is not in accordance with the rules and regulations \\
\hline 6. & There is no stamp on the notarial deed \\
\hline
\end{tabular}

${ }^{5}$ The results of the interview with one of the Members of the Regional Supervisory Board of Padang City, on May 4, 2018 


\begin{tabular}{|l|l|}
\hline 7. & There is no signature on the deed \\
\hline 8. & Notarial deed does not contain names of notary, names of witnesses, and notary stamp \\
\hline
\end{tabular}

Source: Regional Supervisory Board of Padang City

Based on the results of the authors' interview with one of the notaries in Padang City, the notary mentioned that other factors that caused a notary to commit a violation were too-confident feeling and had no desire to join a notary organization. The notary organization is a forum for notaries to share information. In addition, the notary did not give an appreciation for the socialization carried out by the Regional Supervisory Board and some notaries still considered that the Notary Supervisory Board was the party that made them difficult. In fact, the Notary Supervisory Board is the party that protects their dignity as a notary. Furthermore, the new notary does not want to discuss and ask other notaries who have a lot of experience. ${ }^{6}$

According to Muhammad (2009), the basic reasons why notaries tend to violate laws and codes of ethics are:

\section{a. Kinship Influence}

One characteristic of kinship is giving equal respect to family members which are considered fair. It will be different in treating other people who are not family members. This has an effect on the behavior of legal professionalism that is bound to the professional code of ethics which should give equal treatment to clients. Family problems should be separated from professional problems to be considered as fair. Basically, a notary is expected to be able to carry out his position professionally without involving blood or family ties. This problem tends to occur in the application for deed. Both of the clients are family members or other people, the notary must act professionally without distinguishing them. In this way, the notary will not violate the law.

b. Position Influence

One characteristic of position is that subordinates respect and obey superiors; that is the provisions of the employment law. Executive functions are separate from judicial functions. Position problems are supposedly separated from the professional problems to be considered as fair. A professional should work functionally.

\section{c. Consumerism Influence}

The increased expenditure is not balance to the income received by the professionals. This encourages them to seek greater income through short cuts and professional breakthroughs; that is by seeking compensation for services from the parties they serve.

\section{d. Weak Faith Influence}

One of the requirements to become a professional is to devote to God Almighty; i.e. to carry out orders and stay away from His prohibitions. This faith is the basis of human morality. If humans increase faith and piety, human beings will be embedded in morality which becomes a protector of doing bad things.

In the profession of Notaries, these reasons tend to be the reason for notaries in committing violations. To answer the above problems, the authors use the authority theory. Influence component is the use of authority that is intended to control the behavior of legal subjects. The basic component of the

\footnotetext{
${ }^{6}$ The results of the interview with a notary in Padang City on September 19, 2018
} 
law is that the legal basis of an authority can be proven. This can be a guideline for notaries to carry out their positions in accordance with UUJN and Notary Code of Ethics so that they will not violate the law.

\subsection{Actions Conducted by the Regional Supervisory Board against Notaries Who Commit Violations of Law in Padang City}

Supervision, in this case, is a preventive and repressive activity. Preventive means a coaching process while repressive means the imposition of sanctions on a notary who is in carrying out a position proven to violate Law Number 30 of 2004 concerning Notary Position along with Amendment to Law Number 2 of 2014 and violations to the Notary Code of Ethics.The guidance function is intended to supervise and remind the notary to always understand and comply with good rules which are only listed and regulated in the Notary Code of Ethics and the provisions in the applicable Laws and Regulations. All of that is based on the Law or Meaning of Oath of Position which is pronounced and witnessed by the witnesses consisting of executors of oaths and witnesses specifically presented at the event. It must also be borne in mind that the notary oath of position, the notary is also witnessed by God Almighty, the AllKnowing and the Overseeing. In this atmosphere of empathy, it is expected that the notary already has a system of self-defense to ward off anything that can reduce his/her honor and dignity. ${ }^{7}$

The supervisory function to the notary is intended so that, in carrying out his/her position, the notary always complies with the prevailing laws and notary code of ethics. If a notary is proven to have committed a violation, then he/she will be due to sanctions. The Notary Regional Supervisory Board is formed based on UUJN Article 1 paragraph (1) and Article 69 which consisted of 3 elements: notary, academics and government. Meanwhile, the Indonesian Notary Association is an institution formed by a notary professional organization that regulates the issue of a code of ethics in which all members are only notaries. It is stated in Article 82 of the UUJN concerning the notary gathering in one notary organization which is the Indonesian Notary Association.

Referring to the above problems, if a notary is proven to violate the obligations of Article 16 UUJN, the prohibition of Article 17 UUJN and the Code of Ethics, they will be sanctioned. The authority of the Regional Supervisory Board (MPD) has been determined in Article 70 of the UUJN concerning the notary position. Furthermore, the obligations of the Regional Supervisory Board have been determined in Article 71 of the UUJN. Based on Article 70 paragraph 2 of the UUJN, the Regional Supervisory Board of Padang City has the authority to periodically examine the notary protocol 1 (one) time in 1 (one) year at any time necessary. One form of notary responsibility relates to the notary protocol. Article 1 point 13 UUJN states that "the notary protocol is a collection of documents that are state records that must be stored and maintained by a notary in accordance with the provisions of the legislation". Documents including the notary protocol are described in Article 62 UUJN. In certain occasion, notary protocol must be submitted to other parties according to the provisions stipulated in Article 62 of the UUJN where the cause of the notary protocol submission has also been determined (Salim, 2015).

Before the submission of the notary protocol, a notary who wants to transfer his/her place of work must first fulfill the conditions as stipulated in Article 23 of the UUJN. Notary protocol is part of the administration of a notary office that has a very important function and role so that the notary can run a good and correct position. Therefore, the notary protocol, as a state archive, must be organized and managed properly. In addition, notary protocol is supervised by the Notary Supervisory Board or what socalled the Regional Supervisory Board. The Regional Supervisory Board has the authority that is stipulated in Article 70 of the UUJN.

\footnotetext{
${ }^{7}$ The results of the interview with one of the Members of the Regional Supervisory Board of Padang City, on May 5, 2018
} 
Based on the data that the authors obtain, the Area Supervisory Board of Padang, which covers Padang City and Pesisir Selatan District, in 2017 had conducted an examination of the notary protocol. In Padang City, on August 23, 2017, the Regional Supervisory Board of Padang City conducted a notary protocol examination in several places consisting of: Notaries with the initials EFS, N, and HVP. In Pesisir Selatan District on 04-05 May 2017, Regional Supervisory Board of Padang City has carried out notary protocol examination in several places including:

a. In the Notary NB's office which found the following things:

1) Notaries have never sent monthly reports to the regional office or MPD of Padang City

2) Some supporting protocol books have not been signed, numbered and stamped by MPD of Padang City

3) The notary's office does not fulfill the requirements in accordance with the applicable legislation; for instance, there is no guest room and notary room

4) There is a written error in the book in the validity section; the sheet should be closed or glued.

b. In the Notary YAI's office which found the following things:

1) Notaries have never sent monthly reports to the regional office or MPD of Padang City

2) All supporting protocol books have not been signed, numbered and stamped by MPD of Padang City

3) There are still many deeds that have been completed but have not been recorded in the deed register book

4) The notarial deed has not been stamped.

c. In the Notary E's office which found the following things:

1) There are many deeds of 2014-2015 that are not signed and are not stamped.

2) There are many deeds that have been numbered and then considered as null. Those deeds should be included in the deed list if it is indeed null.

3) Deed examination number 21 dated February 6, 2015 has not been signed by the notary.

4) Deeds, that have been issued, have not been transferred to the reportorial book.

d. In the Notary YA's office, as the substitution of Notary M, which found the following things:

1) In the deed list book, there is a deed number that is left blank while the deed has not been issued

2) There are notarial deeds that do not include the name of the notary, the name of the witness, and the notary stamp

3) Waarmerking book still use temporary book. The book should be replaced as soon as possible and signed, stamped and numbered by MPD of Padang City

4) There is no other accompanying protocol book based on law and legislation.

e. In the Notary NR's office

f. In the Notary ER's office

g. In the Notary UI's office

Based on the results of interviews of researchers with one of the members of the Regional Supervisory Board of Padang City, related to the field inspection conducted by the MPD on the notary protocol, the Notary Regional Supervisory Board of Padang City will establish an Examination Board to carry out the inspection process in order to prove whether the notary is violating or not. If the notary concerned is proven to have committed a violation, he/she will be given a written warning so that the notary does not repeat his/her actions. If he/she repeats the violation, the case of position violation can be 
recommended to the level of the Area Supervisory Board and the Central Supervisory Board. Thus, the notary can be subjected to more severe sanctions such as temporary dismissals. ${ }^{8}$

Based on the data that the authors obtain, examination based on the level of Regional Supervisory Committee include:

a. Reports of complaints from the public about alleged position violations and notary codes of ethics submitted through the MPD secretariat. The chairperson of the MPD forms the Regional Examination Council (3 people each element, and is assisted by 1 secretary).

b. Invite the party (in written form) and conduct examination (closed examination for the public).

c. The Regional Supervisory Council must complete its examination and the results shall be submitted to the parties within a period of no later than 30 (thirty) calendar days since the report is received. The results of the examination of the Regional Examination Board are contained in the inspection report and submitted to Area Supervisory Board (MPW) and copies to the related parties (reporter and reported party), Central Supervisory Board (MPP), Regional Administrators, and Indonesian Notary Association.

Based on the data the authors obtain, the examination based on the level of the Area Supervisory Board (MPW) includes:

a. MPW accepted recommendations from the MPD examination

b. The chairperson of MPW forms the Area Examination Board

c. The Regional Examination Board checks the results of the MPD examination (closed examination for the public)

d. The Area Inspection Board has the authority to summon parties to hear their statements (7 calendar days since the file is received)

e. Decision reading (within 30 calendar days since the file was received). The decision contains:

1) Sufficient reason and consideration to be used as the basis for making decisions

2) Decisions are signed by the chairperson, members and secretaries of the Area Supervisory Board

3) If the report cannot be proven, then the report is rejected and the reported party will get his/her reputation back;

4) If the public report can be proven then the reported party (notary) is sanctioned according to the level of violation that he/she committed

5) A copy of the decision of the Area Supervisory Board is delivered to: Ministers, Reporters, Reported Parties, MPD, PP INI, within 30 calendar days since the decision is declared. (If there are objections to the MPW decision, then the legal remedial appeal to MPP can be made within 14 calendar days since the appeal is declared).

To answer this third problem, the author uses the legal certainty theory because according to this theory, law is considered as a system of norms in which the norms themselves contain rules that guide individuals or groups in carrying out community life. Referring to the above problem, it raises binding rules; however, violations still occur. It should have been indicated by the effectiveness of enforcement and action taken by the Regional Supervisory Board of Padang City in conducting legal violations committed by notaries.

\subsection{Regional Supervisors in Preventing Violations of Law Committed by Notaries in Padang City}

\footnotetext{
${ }^{8}$ The results of the interview with one of the Members of the Regional Supervisory Board of Padang City, on May 5, 2018
} 
The implementation of notary's duty as a public official, who has been authorized to serve and obey the law, is realized through compliance with norms and ethics. A notary must have high professional abilities by paying attention to legal norms based on moral integration, nobility, and professional ethics. Thus, trust in the notary position is maintained. It is common that the society expects and demands that the development and implementation of the notary profession is always carried out in accordance with legal norms and professional ethics. This demand is a determining factor for maintaining his/her image as a public official. Notary professional behavior is more focused on the notary's ability/skill. The professional notary lies in the products of the deed that he/she made and the ability to accommodate the expectation of the parties within the deed, fulfil the requirements in making the deed, have a strong issuing power in which words made by the notary are able to become perfect evidence when it is required as evidence. Meanwhile, notary's moral and attitude is a mental attitude that must be owned by a notary in supporting his/her professionalism. A professional who does not have morals will be a money-oriented notary. It needs to be remembered that a notary is a public official who is appointed and dismissed by the state, so he/she must provide good service to all levels of society without discriminating against certain strata or groups and not on the basis of mere money considerations.

In carrying out his/her position, the notary must comply with all moral principles that have lived and developed in the society. In addition to the responsibilities of professional ethics, integrity and good morals are important requirements that must be owned by a notary. Therefore, a notary must always carry out his position in accordance with UUJN and the Notary Code of Ethics.Furthermore, in carrying out their duties and positions, a notary also has obligations that he/she must obey and live in which are stated in Article 16 UUJN. As a public official, the notary also has a prohibition which he must avoid as stated in Article 17 paragraph (1) of the UUJN. In addition, the authority of the Regional Supervisory Board (MPD) has been determined in Article 70 of the UUJN concerning the notary position. The obligation of the Regional Supervisory Board has been determined in Article 71 of the UUJN.

Based on the results of interviews with one member of Regional Supervisory Board of Padang City, there are a lot of reports of notaries who violated the law in cases of violations of notary position throughout 2017. One of the violations of the code of ethics that occurred in the area of the Regional Supervisory Board of Padang City in 2017 based on the minutes of inspection of the number W3.HM.07.01.MPD.PDG-44 in 2017 and based on the minutes of examination 04/BAP/MPDN, there were two notaries violate the provisions of Article 15 letter e of Law Number 30 of 2004 and Law Number 2 of 2014 concerning the notary position, in which the notary does not conduct legal counseling to the public. This violation causes the client to experience a loss when the transfer of rights from the client to another party occurs. In addition, the transfer is carried out by a notary without the knowledge of the rights holders through the intermediary of brokers. ${ }^{9}$

Regarding to this matter, one of the members of the Regional Supervisory Board of Padang City outlined several attempts to prevent violations of law committed by notaries in Padang City. First, it is carried out by implementing preventive supervision; i.e. supervision carried out before the government decision/decree is stipulated or what so-called priory supervision. It will be determined based on government regulations with the implementation of socialization and legal counseling of notaries. Then, it is carried out with repressive supervision, i.e. supervision carried out after the government decision/stipulation is stipulated or after the violation (providing information and counseling) occurs. It is carried out during the trial of cases of violations committed by the notaries to conduct corrective act and restore an erroneous act or what so-called aposterist supervision. Secondly, one of the members of the Regional Notary Supervisory Board of Padang City also explained that they also conducted socialization to parties related to the notary profession under their authority.

\footnotetext{
${ }^{9}$ The results of the interview with one of the Members of the Regional Supervisory Board of Padang City, on May 4, 2018
} 
Based on the data that the authors obtained from MPD on February 13-14, 2018, MPD conducted a socialization on the topic "Socialization of Notary Services", and theme "through the dissemination of this notary service, let's improve the synergy of the Honorary Board of Notaries, the Regional Supervisory Board and the Area Supervisory Board in order to improve the quality of notaries in West Sumatra. "

This socialization aims to:

a. Look for problems and constraints of notaries in providing services to the community;

b. Provide and find effective solutions by perceptions in dealing with problems and constraints of notaries;

c. Disseminate information regarding supervision, guidance and notary services by the government; and

d. Increase understanding, insight, and knowledge of stakeholders in the field of public services including law enforcement agencies so that parties directly related to the notary profession can better understand the newly formed supervisory institution and its authority in maintaining the enforcement of the notary code of ethics.

In addition, socialization is aimed at making the community as users of notary services more aware of their rights and obligations. Therefore, if a violation committed by a notary occurs in the future, the party can report the violation to the Regional Supervisory Board. Furthermore, based on the results of the authors' interview with one of the notaries in Padang City, the notary mentioned that the Regional Supervisory Board was always routinely conducting socialization and legal counseling to notaries in Padang City at least once a year. Commonly, the Regional Supervisory Board always provides socialization at the end of each regional management event or events made by the Regional Supervisory Board. According to the notary, the Regional Supervisory Board of Padang City has a very good performance which they always routinely provide socialization and legal counseling so that the notary avoids violations of the law. In addition, the notary also hopes that the Regional Supervisory Board of Padang City will often carry out activities or socialization of notaries directly sourced from renowned legal experts in Indonesia and so that the Regional Supervisory Board provides a joint secretariat which includes notaries and Notary Supervisory Board of regional government and high-ranking organization. It should be a fixed place for the notary and others to ask each other questions and discuss a problem. In addition, if the Regional Supervisory Board has provided the joint secretariat, notaries and all elements of the Notary Supervisory Board and notary organizations must always maintain and keep that asset or place. ${ }^{10}$

In connection with one of the efforts of the Regional Supervisory Board of Padang City to prevent the occurrence of violations of law committed by a notary in a preventive and curative manner, based on the above provisions, the author tries to identify which authorities include preventive and curative manners.

Preventive authority includes matters regulated in article 70 letters $b, c, d, e, f$ and $h$ UUJN, Article 15 paragraph (2) letters a, b, c, e and f, in which the authority is administrative in nature and more regulating procedural methods and notary protocols. Meanwhile, curative preventive authorities include matters regulated in Article 70 letter a and letter g UUJN, article 15 paragraph (2) letter d which regulates taking action against alleged violations committed by a notary against UUJN and Code of Ethics.

Based on the existence of the Notary Regional Supervisory Board, as the spearhead of the Supervisory Board, the main thing is to prevent the enforcement of the notary code of ethics and supervise the implementation of the notary position. In this case, the Regional Supervisory Board must be

\footnotetext{
${ }^{10}$ The results of the interview with a notary in Padang City on September 19, 2018
} 
responsive in handling violations committed by the notary. In addition, it must also be transparent in handling every case of violation that occurs, so that the authority and quality are maintained in the eyes of the public. The existence of the Regional Supervisory Board may not give the impression that it is an institution that is in the side of the notary. The Supervisory Board must be serious about being an independent institution in carrying out fostering duties to the notary. ${ }^{11}$

The guidance function is intended to supervise and remind the notary to always understand and comply with good rules which are only listed and regulated in the Notary Code of Ethics and the provisions in the applicable Laws and Regulations. All of that is based on the Law or Meaning of Oath of Position which is pronounced and witnessed by the witnesses consisting of executors of oaths and witnesses specifically presented at the event. It must also be borne in mind that the notary oath of position, the notary is also witnessed by God Almighty, the All-Knowing and the Overseeing. In this atmosphere of empathy, it is expected that the notary already has a system of self-defense to ward off anything that can reduce his/her honor and dignity.

Based on the results of interviews with one of the members of Regional Supervisory Board of Padang City from the government element, Mrs. Desmawita, she mentioned that the large area and the number of notaries constituted a constraint or obstacle to supervise and guide them. This certainly becomes less effective because it is quite time consuming and labor intensive to carry out the duties and functions of the Regional Supervisory Board of Padang City.

There are other things which certainly hinder the implementation of the duties of the Regional Supervisory Board of Padang City. She said that the Notary Regional Supervisory Board of Padang City consists of 3 (three) elements including notaries, academics, and government. This has become a separate obstacle caused by the busyness of each member and this has an impact on the time available to carry out the duties of the Notary Regional Supervisory Board of Padang City in supervising and guiding the notaries. In addition to the time and busyness of the members, the large area and the number of notaries also become benchmarks in effectively supervising and fostering them. However, apart from that, every member of the Regional Supervisory Board of Padang City always establishes communication to facilitate the duties and authority of the Regional Supervisory Board of Padang City either by telephone and social media regarding reports or complaints such as violations of the code of ethics or UUJN from the public. The members always coordinate with the Chairperson of the Regional Supervisory Board of Padang City to establish the Examination Board which is formed to carry out the inspection process for the public's report.

In the discussion on the formulation of this second problem, the author applies the legal responsibility theory. It is a theory that analyzes the responsibilities of legal subjects or actors who have committed acts against the law or criminal acts to bear costs or losses or carry out crimes for their mistakes or for negligence. It can be a guideline for the Notary Regional Supervisory Board to optimize performance in order to prevent legal violations committed by notaries. Thus, the notary can carry out his/her position in accordance with what has been mandated by UUJN.

\section{Conclusions}

Violations of the Notary Position Act committed by notary in the preparation of deeds include: the deed is made without witnesses, the deed is not read by a notary, the deed is not signed before a notary in which the deed is carried by another person and signed by and in an unknown place by the notary, the notary makes a deed outside the area of his/her position and lists the information in the deed as if it is made in the notary's place of work. The factor causing the violation of law committed by the

\footnotetext{
${ }^{11}$ Interview a member the Regional Supervisory Board of Padang City, on May 5, 2018
} 
notary in Padang City is the absence of an appreciation from the notary for the socialization carried out by the Regional Supervisory Board of Padang City and a new notary who does not want to discuss or ask other notaries who have a lot of experience. In addition, the notary likes to accept work that is not in accordance with the date specified within the deed and often does not make face-to-face meetings with the client. Furthermore, it is known that this is one of the triggers for the notary in violating the law. In this regard, the basic reasons why the notary tends to violate the law and the code of ethics can be inventoried; i.e. the kinship influence, position influence, consumerism influence, and weak faith.

The action taken by the Regional Supervisory Board against the notary who committed a violation of law in Padang City is by establishing an Examination Board to carry out the examination process and prove whether or not the notary is committing a violation. If the notary is indeed proven to have committed a violation of position, then he/she will be given a written warning to avoid repeating his/her violations again. If he/she repeats the mistake again, cases of official violations can be recommended to the level of the Area Supervisory Board and the Central Supervisory Board so that he/she can be subjected to more severe sanctions such as temporary dismissals. At the examination stage, the Regional Supervisory Board of Padang City carries out the system based on the applicable Law so that they continued to uphold the rights and justice of the parties.

The role of the Regional Supervisory Board in preventing the legal violations committed by notaries in Padang City is to implement two ways of supervision. First, it is carried out by implementing preventive supervision; i.e. supervision carried out before the government decision/decree is stipulated. Second, it is carried out with repressive supervision, i.e. supervision carried out after the government decision/stipulation is stipulated or after the violation (providing information and counseling) occurs. It is carried out during the trial of cases of violations committed by the notaries to conduct corrective act and restore an erroneous act or what so-called aposterist supervision. Moreover, one of the members of the Regional Notary Supervisory Board of Padang City also explained that they also conducted socialization to parties related to the notary profession under their authority. This socialization aims to make all parties directly related to the notary profession understand more about the existence of a newly formed supervisory institution and understand its authority in maintaining the enforcement of a notary code of ethics. In addition, the socialization was aimed at making the public as users of notary services more aware of their rights and obligations. Thus, if in the future violations committed by a notary occur, the party can report the violations to the Regional Supervisory Board. Later, the Regional Supervisory Board immediately looked at the location to foster and give good advice to the notary if he/she did make a mistake.

\section{References}

Adjie, Habib. 2009. Meneropong khazanah notaris dan PPAT Indonesia: kumpulan tulisan tentang notaris dan PPAT. Jakarta: Citra Aditya Bakti.

Braithwaite, John. 2002. "Rules and principles: A theory of legal certainty." Austl. J. Leg. Phil. 27.47.

Buchanan, John, Dominic Heesang Chai, and Simon Deakin. 2014. "Empirical analysis of legal institutions and institutional change: multiple-methods approaches and their application to corporate governance research." Journal of Institutional Economics.10.1:1-20.

Fauzi, Machmud. 2008. Kewenangan Majelis Pengawas Cerminkan Kelembagaan Notaris.

Habermas, Jürgen. 2015. Between facts and norms: Contributions to a discourse theory of law and democracy. John Wiley \& Sons. 
Hardjasoemantri, Koesnadi. 1994. Hukum tata lingkungan (No. 1). Gadjah Mada University Press.

Kelsen, Hans. (2017). General theory of law and state. Routledge.

Koentjoro, Diana Hakim. 2004. Hakim Administrasi Hukum. Bogor: Ghalia Indonesia.

Marzuki, Peter Mahmud. 2009. Pengantar Ilmu Hukum, Cetakan Kedua, Jakarta: Kencana Prenada Media Group.

McConville, Mike. 2017. Research methods for law. Edinburgh University Press.

Muhammad, Abdulkadir. 2009. Etika Profesi Hukum. Jakarta: Citra Aditya Bakti.

Raitio, Juha. 2003.The principle of legal certainty in EC law. Vol. 64. Springer Science \& Business Media.

Salim, Haji Said. 2015. Teknik Pembuatan Akta Satu (Konsep Teoritis, Kewenangan Notaris, Bentuk dan Minuta Akta), Jakarta: PT. Raja Grafindo Persada.

Salim, Haji Said \& Nurbani, Erlies Septiana. 2014. Penerapan Teori Hukum Pada Penelitian Disertasi dan Tesis. PT Raja Grafindo Persada, Jakarta.

Yudara, N.G. 2006, Notaris dan Permasalahannya (Pokok-Pokok Pemikiran di Seputar Kedudukan dan Fungsi Notaris Serta Akta Notaris Menurut Sistem Hukum Indonesia), Makalah disampaikan dalam rangka Kongres INI di Jakarta), Majalah Renvoi Nomor 10.34.III, Edisi 3, Hlm. 72.

\section{Copyrights}

Copyright for this article is retained by the author(s), with first publication rights granted to the journal.

This is an open-access article distributed under the terms and conditions of the Creative Commons Attribution license (http://creativecommons.org/licenses/by/4.0/). 